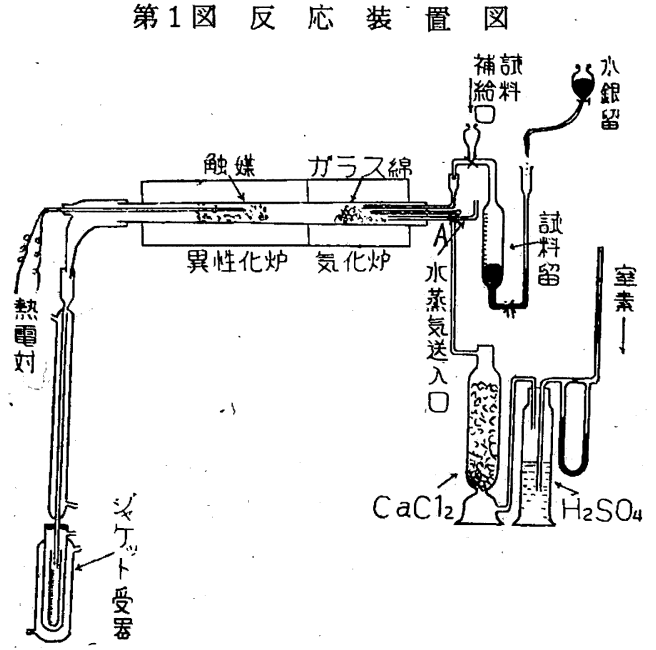

$155 \sim 165^{\circ} \mathrm{C}$ の二つの留分は合して再分留し， $159 \sim 161^{\circ} \mathrm{C}$ 留分 をとり，ベルトラム加水法により，イソボルネオールとし，純品 と混融してこの留分中にカンフェンを確認し, 眽酸イソボルネオ ールのエステル価より収量を算出した。

カンフェンを除いた $159^{\circ} \mathrm{C}$ 以下は未反応ピネンとした。

また $175 \sim 180^{\circ} \mathrm{C}$ 留分より $175 \sim 177^{\circ} \mathrm{C}$ 留分を精留し, 臭素付 加物 (mp 122 123ㅇ) を生成せしめ, 純ジペンテンテトラブロ マイドと混融して、゙ジペンテンの存在を確認した。

本研究は著者らか阪大工学部に在籍中行ったもので, 井本稔教 授（現阪市大）就よび荒川林産合資会社の御援助を深謝する。

\title{
（205） p-シメンの加圧酸化によるテレフタル酸の合成
}

(昭和 30 年 11 月 17 日受理)

大平愛信・鳥居忠彥・山本隆造・堤繁*

\section{I. 緒言}

テリレンはナイロンとともに最む期待される合成絨維である が，テリレンの主要原料であるテレフタル酸の合成が, テリレン 彗造の重要な課題となっている。従来テレフタル酸の合成は $p$ キシレンの酸化によってきたが，原料を $p$-キシレンに求めるこ とはわが国に执いては資源的に相当困難な問題である。

上の点から，著者らは原料として新しく $p$-シメンを取りあげ た。pーシメンは元来本邦においては亜硫酸パルプ製造の副産物と して得られてきたが，その生産量はテリレン原料として，あまり にも乏しい嫌いがある。一方著者らの研究室において試みられて

$\dagger$ 本報を「テレフタル酸の合成に関する研究 (第 1 報)」とす る.

* 大阪大学工学部応用化学教室：大阪市都島区.

1）増尾, 加藤, 工化 55, 166 (1952).

2) 井本, 黄, 工化 $57,458,460$ (1954).

3) 岡田, 伏崎, 工化 57, 301 (1954).
きた石油のクラッキングから得られるプロピレンを, プラットホ ーマーより得られるトルェンに反応させて, 収量よくp-シメン をえる研究が今や工業化の段階にある現状から， pーシメンの供給 はすべてこれによることがでさるようになった。

$p$-シメンの液相空気酸化については種々報告されているが1 3), 著者らは加圧釜中酸素加圧下において酸化を行った。

\section{II. 実 験 方 法}

試料 pーシメンは濃硫酸でふりまぜたのち, ヘリックス・カラ ムで精留し bp 174 $178^{\circ} \mathrm{C}$ の留分をとり，p-シメン中に $\alpha$-メチ ルスチレンが微量にでも存在すると, 酸化反応がいちじるしく阻 害されるので, これを水素化して $p$-シメンとするため, ラネ一 ニッケルで常温 $60 \mathrm{~atm} 5$ 時間水素添加を行い, さらにヘリック ス・カラムで精留し, bp $177^{\circ} \mathrm{C}$ の留分 $\left(n_{\mathrm{D}}^{20} 1.4909, d_{4}^{20} 0.8573\right)$ を原料とした。

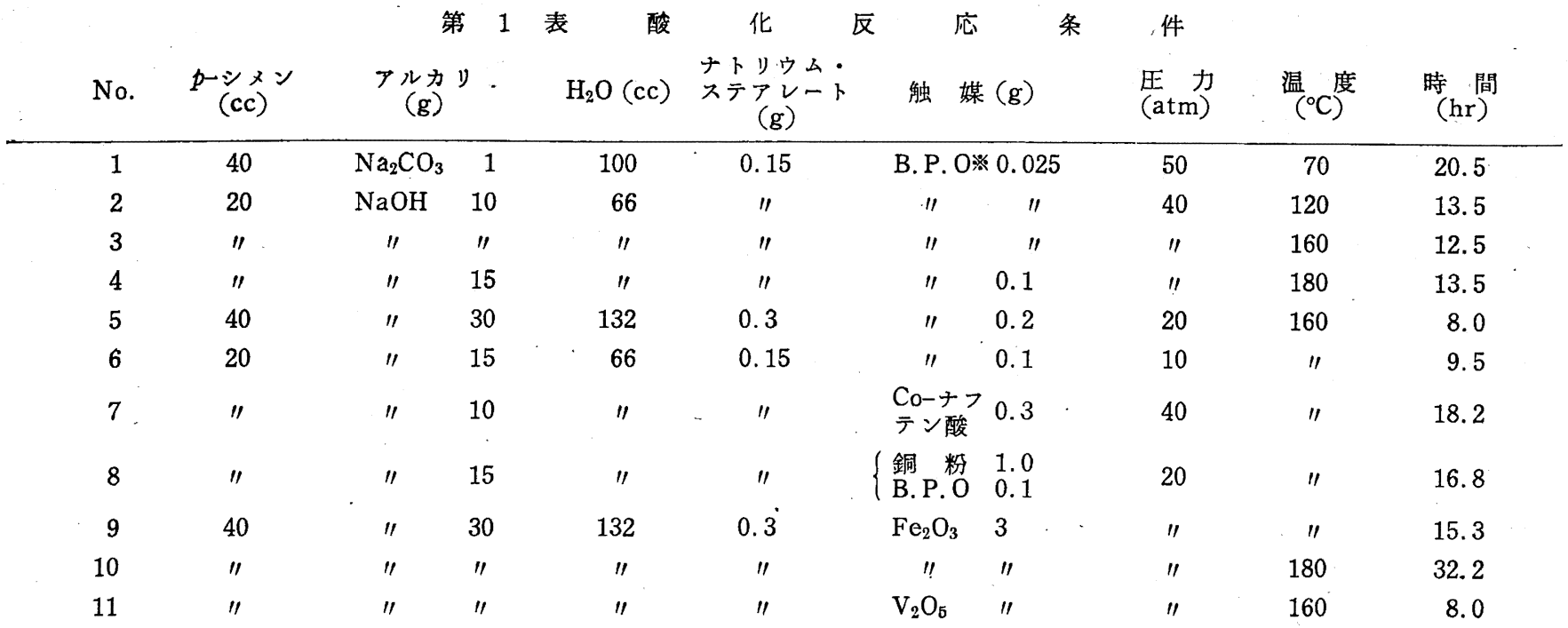

※ B.P.O： ベンジイルパーオキサイド 
触媒 ベンゾイルパーオキサイドはクロロホルムとメタノール で再結晶を行い, $\mathrm{mp} 103^{\circ} \mathrm{C}$ のものを用い，金属酸化物は市販の ものを使用した。

実験操作 横型ふりまぜ式内容 $1 l$ の加圧釜に, p-シメン, 水, アルカリ, 触媒, ナトリウム・ステアレートをいれ, 酸素加 圧下に反応を行った（第 1 表）。

生成物の分析 反応生成物を熱カセイソーダ水溶液 (10\%) で 洗い, エーテル抽出したのち, 油層を分留して未反応 $p$-シメン 留分， pーメチルアセトフェノンと $p$-トリルメチルカルビノール の混合留分（bp $110 \sim 120^{\circ} \mathrm{C} / 11 \mathrm{mmHg}$ ) とに分ける。有機酸分を 塩酸酸性後, 口過, 抽出, 減圧景華にて, テレフタル酸, クミン 酸, ートリル酸を単離する。

生成物の磪認 テレフタル酸: $\mathrm{mp} 280^{\circ} \mathrm{C}$ 以上の酸をエステル 化し, ジェチルエステル $\left(\mathrm{mp} 41 \sim 42^{\circ} \mathrm{C}\right)$ をえた。クミン酸：減 圧昇華（bp 95 $110^{\circ} \mathrm{C} / 12 \mathrm{mmHg}$ ）後, 水より再結晶を行い, $\mathrm{mp} 117^{\circ} \mathrm{C}$ の白色結晶をクミン酸とする。トリル酸：減圧昇華 (bp $125 \sim 150^{\circ} \mathrm{C} / 12 \mathrm{mmHg}$ ) 後, 水にて再結晶を行い, $\mathrm{mp} 170^{\circ} \mathrm{C}$ の白色結晶を $p$-トリル酸とする。pーメチルアセトフェノン: bp $110 \sim 120^{\circ} \mathrm{C} / 11 \mathrm{mmHg}$ の淡黄色液体 $\left(n_{\mathrm{D}}^{22} 1.5183\right)$ で, 2,4-ジニト ロフェニルヒドラゾン $\left(\mathrm{mp} 250^{\circ} \mathrm{C}\right)$ をあたえる。pートリルメチル カルビノール: bp $110 \sim 120^{\circ} \mathrm{C} / 11 \mathrm{mmHg}$ の留分はジアゾ呈色反 応, ドニイゲ反応が陽性であるから, 上のカルビノールの存在が 推測されるが, 単離は行わなかった。

\section{III. 実験結果ならびに考察}

第 2 表はテレフタル酸拉よび $p$ メチルアセトフェノンの理論 収量および酸素吸収百分率※を示す。

\begin{tabular}{|c|c|c|c|}
\hline No. & $\begin{array}{l}\text { か-メチルアセ卜 } \\
\text { フェフシ (\%) }\end{array}$ & $\begin{array}{c}\text { テレフタル酸 } \\
(\%)\end{array}$ & $\begin{array}{c}\text { 酸秦吸収 } \\
(\%)\end{array}$ \\
\hline 1 & 7.8 & 4.7 & 22.5 \\
\hline 2 & 4.3 & 31.4 & 31.5 \\
\hline 3 & 10.8 & 50.0 & 70.0 \\
\hline 4 & - & 16.8 & 200.0 \\
\hline 5 & 2.5 & 44.0 & 81.0 \\
\hline 6 & 3.4 & 29.5 & 57.0 \\
\hline 7 & 1.6 & 34.0 & 80.0 \\
\hline 8 & 4.1 & 43.5 & 80.0 \\
\hline 9 & 10.4 & 62.0 & 81.0 \\
\hline 10 & 0.6 & 18.0 & 83.0 \\
\hline 11 & 2.0 & 4.8 & 35.4 \\
\hline
\end{tabular}

反応温度の影釷 反応温度の上昇とともに酸素吸収量が增加 し，その活発な吸収温度は $140 \sim 150^{\circ} \mathrm{C}$ 付近である。第 1 㓙に示 すよ5に反応時間とともに酸素吸収量の減少がみられる。しかし No. 4 はその酸素吸収量が大きくかつ反応速度も大きいが，第 2 表にみられるよらにテレフタル酸の収量がきわめて悪い。これは 温度上昇のために生成された酸の脱炭酸反応が起っている結果で ある。本酸化反応においては, $160^{\circ} \mathrm{C}$ が最も適当である。

酸素圧力の影望 酸素圧力は No. 3 と No. 5 を比較すること によってわかるよ5に, 初圧 $20 \mathrm{~atm}$ で十分な反応速度が得られ る。この事実は操作上多くの困難性をむつ本実験においてとくに 重要なことである。

アルカリの影響 炭酸ソーダの使用よりもカセイソーダがすぐ れている。これは生成された酸が塩となり，水にとけて反応が均 一反応となり，反応速度が大きくなるためか，生成されたカルホ়

兴 後述の酸华メカニズムに基く酸素吸収百分率である，
第 1 図 反応時間と酸素吸収王との関係

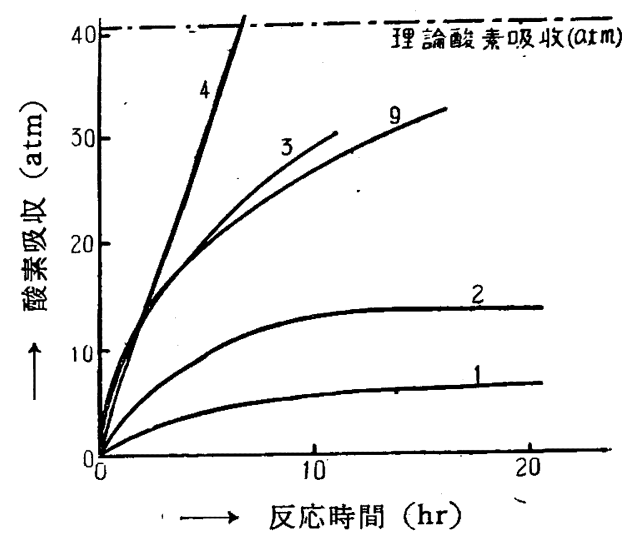

ニル化合物のエノレ化が酸への酸化に影響しているためであろ5。

触媒の影響 第2図名らわかるよ5に, 反応の初期において B.P.O. はすでに低温で著しい活性化反応を示す。

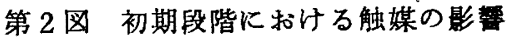

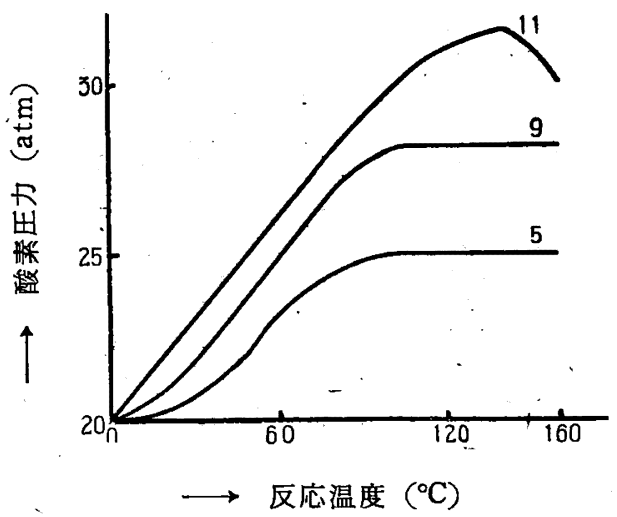

しかるに, テレフタル酸の生成は, B.P.O.よりす $\mathrm{Fe}_{2} \mathrm{O}_{3}$ がす ぐれている。また ル酸に対し, No. 3 に拈いて $21.6 \%$ で, No. 9 において 16.8 \%である。

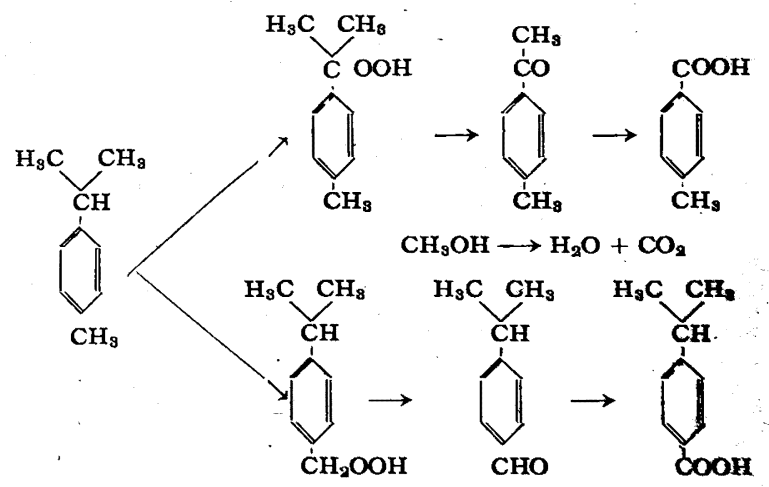

そしてテレフタル酸の収量は, No. 9 で最高を示し, 理論収量 $62 \%$ ，究極収量 $82 \%$ であった。

気相酸化においてすぐれた触媒である $\mathrm{V}_{2} \mathrm{O}_{5}$ が, 本酸化反店に おいてはあまり効果を示さないことは興味深い。

\section{総括}

1） p-シメンのアルカリ水溶液を、ベンソ゚イルパーオキサイド や， $\mathrm{Fe}_{2} \mathrm{O}_{3}$ のよ 5 な金属酸化物を触媒として，加圧酸化をおこな い, 触某が $\mathrm{Fe}_{2} \mathrm{O}_{3}$ のとき, $20 \mathrm{~atm}, 160^{\circ} \mathrm{C}$ で理論収量 $62 \%$, 究 極収量 $82 \%$ でテレフタル酸をえた。

（昭和 30 年 4 月 3 日，日化第 8 年会講演） 